\title{
Effect of Rootstock on the Incidence of Dying Arm of Chenin blanc vines
}

\section{J. H. S. FERREIRA}

Viticultural and Oenological Research Institute, Private Bag X5026, 7600 Stellenbosch, Republic of South Africa.

Submitted for publication: September 1984

Accepted for publication: March 1985

Keywords: Rootstocks, Dying Arm, Vitis vinifera

\begin{abstract}
A survey was conducted over a period of three seasons to determine the incidence of dying arm on Vitis vinifera $\mathbf{L}$. cv. Chenin blanc grafted on 11 rootstock cultivars in an existing rootstock trial. A significant seasonal increase in dying arm was observed from 1979 to 1981 . Fewer vines with dying arm symptoms occured where Chenin blanc was grafted on $V$. rupestris cv. Rupestris du Lot and V. champini cv. Ramsey compared to the rest of the rootstock cultivars. Chenin blanc grafted on 101-14 Mgt and $3306 \mathrm{C}$ rootstocks exhibited the highest incidence of dying arm symptoms. This difference in disease incidence in rootstock cultivars is of utmost importance and could be helpful in controlling the disease.
\end{abstract}

Dying arm is a serious wood rot disease of vines in the Western Cape and is considered one of the main reasons for the limited economically productive life of vineyards. Symptoms of this disease are well documented (Moller, Kasimatis \& Kissler, 1974; Bolay \& Moller, 1977; Moller \& Lehoczky, 1979). Although several cultivars on which dying arm symptoms occurred, are mentioned in the literature (Moller \& Kasimatis, 1975; Wicks, 1975; Kouyeas, et al., 1976), references are lacking as regards the susceptibility to the disease of different scion cultivars. The effect of rootstock cultivars on the incidence of dying arm disease on scion cultivars is not documented either.

A survey was carried out over a period of three years in an existing rootstock trial to determine the effect of the rootstock cultivar on disease development in Chenin blanc, as well as the seasonal occurrence of the disease.

\section{MATERIALS AND METHODS}

The trial consisted of 11 rootstock cultivars with four plots of 42 vines per rootstock cultivar. The scion and rootstock cultivars were 14 years old at commencement of the survey. The presence or absence of the disease on the scion cultivar was recorded for the different rootstocks at the start of the vegetative season. Rootstock cultivars were: 101-14 Mgt, 3306 C, 143B Mgt, Jacquez, 99 Richter, 420A Mgt, Dogridge, 110 Richter, Teleki, Ramsey and $V$. rupestris cv. Rupestris du Lot. Arcsin transformation (Snedecor, 1956) was carried out on the data before applying analysis of variance. Means comparison was conducted by using the Scott \& Knott cluster method (Scott \& Knott, 1974).

\section{RESULTS AND DISCUSSION}

The mean percentage affected vines increased highly significantly each year from 1979 to 1981 (Table 1) indicating the rapid spread of the disease.

The mean percentage dying arm affected Chenin blanc vines grafted on different rootstocks is presented in Table 2 . Significantly less vines with dying arm symptoms occurred
TABLE 1

Mean percentage dying arm affected Chenin blanc vines for 11 rootstocks during three seasons, Stellebosch

\begin{tabular}{c|c}
\hline Season & Mean* \\
\hline 1979 & $13,88 \mathrm{a}$ \\
1980 & $23,92 \mathrm{~b}$ \\
1981 & $28,65 \mathrm{c}$ \\
\hline
\end{tabular}

* Means followed by different letters differ significantly at $\mathrm{P}=0,01$

TABLE 2

Mean percentage dying arm affected Chenin blanc vines on 11 different rootstocks during three seasons

\begin{tabular}{l|l}
\hline Rootstock & Mean* \\
\hline $101-14 \mathrm{Mgt}$ & $25,91 \mathrm{a}$ \\
$3306 \mathrm{C}$ & $25,84 \mathrm{a}$ \\
$143 \mathrm{~B} \mathrm{Mgt}$ & $24,47 \mathrm{~b}$ \\
Jacquez & $24,23 \mathrm{~b}$ \\
99 Richter & $23,64 \mathrm{~b}$ \\
420 A Mgt & $23,38 \mathrm{~b}$ \\
Dogridge & $21,61 \mathrm{c}$ \\
110 Richter & $20,87 \mathrm{c}$ \\
Teleki & $20,36 \mathrm{c}$ \\
Ramsey & $18,28 \mathrm{~d}$ \\
Vitis rupestris cv. & $12,70 \mathrm{e}$ \\
Rupestris du Lot & \\
\hline
\end{tabular}

* Means followed by different letters differ significantly at $\mathrm{P}=0,01$

in Chenin blanc grafted on $V$. rupestris cv. Rupestris du Lot and Ramsey. Grafts of Chenin blanc on 101-14 Mgt and $3306 \mathrm{C}$ showed significantly more vines with dying arm symptoms.

These results clearly indicate that the dying arm disease may develop rapidly. Chenin blanc appears to differ in its susceptibility to the disease, depending on rootstock cultivar. The reasons for this phenomenon are unknown but could possibly be ascribed to inherent resistance and/or vigor induced by the rootstock.

Choice of rootstock cultivar may therefore aid in prolonging the economically productive life of a vineyard. This aspect merits further research. 


\section{LITERATURE CITED}

BOLAY, A. \& MOLLER, W. J., 1977. Eutypa armeniacae Hansf \& Carter agent d'un grave dépérissement de vignes en production. Rev. suisse arboric Hortic. 9, 241-152.

KOUYEAS, H., CHITZANIDIS, A., PAPPAS, A. \& CARTER, M. V., 1976. Eutypa armeniacae on apricot and grapevines in Greece. Phytopath. Z. 87, 260-263.

MOLLER, W. J. \& KASIMATIS, A. N., 1975. Newly recognised dying arm disease on grapevines, California Agriculture 29, 10-11.

MOLLER, W. J., KASIMATIS, A. N. \& KISSLER, J. J., 1974. A dying arm disease of grapevine in California. Pl. Dis. Reptr. 58, 869-871.
MOLLER, W. J. \& LEHOCZKY, J., 1979. The occurrence of Eutypa dieback of grapevine in Hungary. Phytopath. Z. 99, 116-125.

SCOTT, A. J. \& KNOTT, M., 1974. A cluster analysis method for grouping means in the analysis of variance. Biometrics 30, 507-510. SNEDECOR, G. W., 1956. Statistical methods (5th edit.). Iowa State University Press, Ames., Iowa. $534 \mathrm{pp}$.

WICKS, T., 1975. The dying arm disorder of vines in South Australia. Agric. Record. South Australia 2, 14-20. 